\title{
Are carbohydrate storage strategies of trees traceable by early-latewood carbon isotope differences?
}

\author{
Adam Kimak • Markus Leuenberger
}

Received: 16 September 2014/Revised: 20 January 2015/ Accepted: 30 January 2015/Published online: 11 February 2015

(C) The Author(s) 2015. This article is published with open access at Springerlink.com

\begin{abstract}
Key message Investigations of stable isotopes in earlyand latewood cellulose offer interesting insights to climate-driven adaptations of trees' carbon storage strategy during different phenological phases.

Abstract We investigated $\delta^{13} \mathrm{C}$ isotopic composition in both earlywood and latewood. The origin of the samples is an oak forest (Quercus petraea), situated in Switzerland. A comparison of isotope compositions between early- and latewood can help us to investigate and understand the processes of plant metabolism in more detail. The fact which we found excellent correlations $\left(r^{2}=55 \%\right)$ between early- and latewood for carbon isotopes strengthens the common knowledge that atmospheric $\mathrm{CO}_{2}$ acts as the major carbon source for latewood but the earlywood strongly depends on the reserves from previous years $\left(r^{2}=68 \%\right)$, at least for oaks investigated in this study. In addition, that no correlation between late woods $\left(r^{2}=0-5 \%\right)$ was found, manifests the higher variability of direct assimilates. Furthermore, we examined the impacts of increasing air temperature and $\mathrm{CO}_{2}$ concentration on carbohydrate fluxes in trees and we found remarkable differences between two time periods. In the period $\mathrm{AD}$ $1780-1825$, the trees intensely used the young reserves while in the period AD 1960-1994, there is no clear preference of them. This suggests that in the latter period, a larger volume of reserves is available and that the new
\end{abstract}

Communicated by A. Gessler.

A. Kimak $(\bowtie) \cdot$ M. Leuenberger

Climate and Environmental Physics, Physics Institute and

Oeschger Centre for Climate Change Research, University

of Bern, Bern, Switzerland

e-mail:kimak@climate.unibe.ch assimilated reserves (previous year) do not play the most important part, mainly due to the very favourable conditions induced by climate change, at the investigated site. In conclusion, a carbon isotope approach on early- and latewood samples is ideal to investigate isotope incorporation pathways of physiological processes. This will augment the interpretation of tree ring isotope records with respect to the assignments of their variations to specific biochemical processes within the tree, i.e. carbon allocation.

Keywords Earlywood - Latewood C Carbon isotope . Tree ring

\section{Introduction}

The analyses of isotope compositions of tree rings have become an increasingly important source of information integrating diverse fields, i.e. dendrochronology and paleoclimate research. It is well-established that trees use direct (assimilation) and indirect (from carbon storage) pathways to build carbohydrates during metabolic processes (Kozlowski 1992). Associated with these physical and biochemical processes of sugar, starch, lignin, cellulose and other compound formation within the tree are isotope fractionations. The determined signal of stable isotopic composition in tree ring carbohydrates informs us about the history of the trees' life. This allows us to investigate the intra- and inter-annual meteorological conditions, the hydrological setting and also the plant physiological processes (McCarroll and Loader 2004).

Many studies in Europe investigated the oak species because of its longevity, its relatively well cross datable ring widths and its high sensitivity to inter-annual environmental changes (Loader et al. 2003; McCormac et al. 
1994; Wilkinson et al. 2012). Moreover, the oak forms large vessels for increasing water and nutrient transport at the beginning of vegetation, which allows an easy distinction of the early- and latewood phase and facilitates investigations on the intra-annual variability (Feuillat and Keller 1997; Schweingruber 1996). Therefore, we chose Quercus petraea for our investigation.

The deciduous species have four different phases in the aspect of ring growth (Pallardy 2008). The four phases [earlywood (EW), transition, latewood (LW) and winter phase] follow each other and change dynamically depending on environmental conditions (Chmielewski et al. 2004; Morin et al. 2010). Due to the acceleration of global change through the last century, the phenological phases shifted, strongly documenting how the warming climate results in a significant influence on the tree phenology (Defila and Clot 2005). Generally, the EW formation starts after winter as soon as the environmental conditions are suitable, consequently at the beginning of spring. The stored starch and sugars are used to build the new tissues. Early after budburst, the tree is able to photosynthesize carbohydrates in a self-contained way. The transition area is the tree ring part for which the reconverted stored materials and direct assimilates are used at the same time for cellulose formation. After the tree reached the optimal leaf area, the carbohydrates originate from direct assimilation (Keel and Schadel 2010). The LW period is typically between the end of May and end of July, when the tree ring growth slows down and stops while the trees photosynthesize carbohydrates until defoliation, which in Central Europe occurs around the end of October (Barbaroux and Bréda 2002; Michelot et al. 2012). Some of the synthetized carbohydrates are used for metabolic processes, another part is moved to phloem to build the new plant tissues above and below ground while the last part is moved to the roots and stored as starch to secure the plant against winter conditions and to ensure sufficient materials for the new EW and budburst (Pallardy 2008; Rowell 2005).

The isotopic signal is primarily imprinted in plant cellulose influenced by climate and metabolic process variabilities. Gessler et al. 2009 summarised the plant-related processes that potentially influence the carbon and oxygen isotopic composition of organic matter in plants. The carbon isotopes are influenced by photosynthetic carbon discrimination (Farquhar et al. 1982), by post-carboxylation carbon isotope discrimination in autotrophic tissues (Gessler et al. 2008; Hobbie and Werner 2004; Tcherkez et al. 2004) and by post-carboxylation carbon isotope discrimination in heterotrophic tissues (Helle and Schleser 2004; Michelot et al. 2012).

Furthermore, the tree internal material transport has not only intra-annual but also inter-annual implications.
Due to the carbon storage and reconversion effect, the starch stores the climate signal of the current year latewood period and transfers it later on to the earlywood cellulose. This is readily observed but is strongly species dependent. Evergreen species show a lower coherence between the earlywood and the latewood (Jäggi et al. 2002; Kress et al. 2009b) while for the deciduous species a more dynamic transport between the storage and the EW tissues is observed (Hill et al. 1995; Switsur et al. 1995).

Previous studies determined the intra-annual variability for carbon isotopes (Helle and Schleser 2004; Leuenberger et al. 1998; Li et al. 2005). They also found an isotopic offset between the carbon isotopic composition of EW and LW cellulose where the EW is more positive as expected because of the use of isotopically enriched reserves (Gessler et al. 2014; Rossmann et al. 1991; Tcherkez et al. 2004).

In this study, we sampled oak species to investigate the carbon storage usage under changing living conditions with the help of stable isotope signals and hypothesise that EW to LW carbon isotope differences mirror carbohydrate storage strategies. Thus, for both $\mathrm{EW}$ and LW we measured carbon stable isotopes in two different time periods having very different meteorological conditions (AD 1780-1825 and $\mathrm{AD}$ 1960-1994) for a better understanding of the tree phenology and its influences on redistributions of reserves and on stable isotope fractionations.

\section{Materials and methods}

The sample site is a permanent managed oak forest (Quercus petraea.) that is situated in the Swiss "Mittelland", about $20 \mathrm{~km}$ west of Bern, near Salvenach, shown in Fig. 1. The annual precipitation amount is approximately $1,000 \mathrm{~mm} /$ year, with a slight maximum from May to $\mathrm{Au}-$ gust $(100 \mathrm{~mm} / \mathrm{month})$. The annual temperature is approximately $8.5^{\circ} \mathrm{C}$ with amplitude of $18{ }^{\circ} \mathrm{C}$ between January $\left(0^{\circ} \mathrm{C}\right)$ and July $\left(18^{\circ} \mathrm{C}\right)$. The site has been sampled in winter 1994-1995. All oak trees of the sampling site started to germinate AD 1720-1730.

To complete our proxy, we measured the tree ring widths (TRW). The TRWs were not measured separately for EW and LW. Therefore, the following results of the correlation coefficients correspond to whole ring widths. The TRW Sal represents the total tree ring widths for the single core that has been used for the isotope analysis while the TRW mean denotes the average TRW data of different cores originating from eight single trees from the surrounding area. The TRW results have a resolution $0.01 \mathrm{~mm}$ using a LINTAB measuring table (Rinn 2004) (http://www. rinntech.de/images/stories/PDF/LINTAB-5.pdf). 


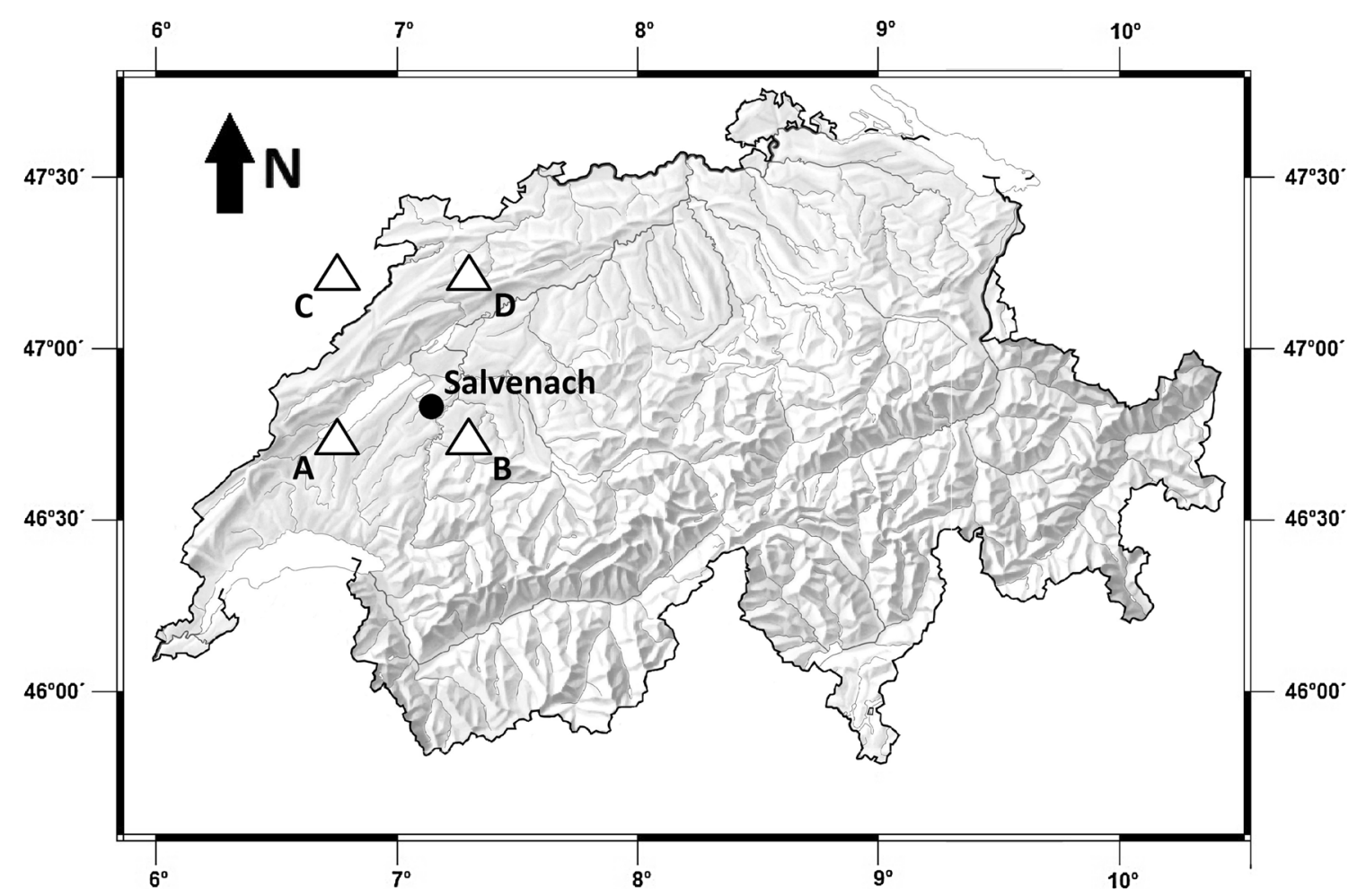

Fig. 1 Map of Switzerland where the black circle denotes the location of Salvenach $\left(46^{\circ} 45^{\prime} 50^{\prime \prime} \mathrm{N} / 7^{\circ} 10^{\prime} 20^{\prime \prime} \mathrm{E}\right)$, the oak sampling site, while the four triangles denote the coordinates of the applied

After cross dating all our wood cores EW and LW were separated, milled and subsequently the cellulose was extracted according to the method described by Borella et al. (1998), Boettger et al. (2007) and Laumer et al. (2009). To avoid the "juvenile effect" (Leavitt 2010) that is able to impact tree ring widths and isotopic composition, we investigated the time period $\mathrm{AD} \quad 1780-1825$ and $\mathrm{AD}$ 1960-1994.

The time period AD 1780-1825 is well-known as "cold" period due to lower insolation (Dalton minimum) and an accumulation of volcano eruptions [unknown eruption (1809), Tambora, (1815); (Gao et al. 2008)] while the period AD 1960-1994 is warmer at least partly due to changes in atmospheric $\mathrm{CO}_{2}$ and thereby in air temperature (Büntgen et al. 2006; Casty et al. 2005; IPCC 2013; Luterbacher et al. 2002).

For the carbon isotopic composition analysis, we intentionally pooled four cores from different directions drilled at the same height of one tree (Sa1) since the high natural variability of tree ring records might lead to cancelling effects of intra-annual variations when pooling across cores of multiple trees. Ideally, several single core analyses with differentiation of early- and latewood should be performed per tree. In this sense, these measurements are a pilot study. For isotope analysis, we used a conventional IRMS spectrometer coupled to a thermo chemical temperature reconstructions described by Casty et al. (2005). $A, B$, $C$ and $D$ coordinates are $46^{\circ} 45^{\prime} \mathrm{N} / 6^{\circ} 45^{\prime} \mathrm{E}, 46^{\circ} 45^{\prime} \mathrm{N} / 7^{\circ} 15^{\prime} \mathrm{E}, 47^{\circ} 15^{\prime} \mathrm{N} /$ $6^{\circ} 45^{\prime} \mathrm{E}, 47^{\circ} 15 \mathrm{~N} / 7^{\circ} 15^{\prime} \mathrm{E}$, respectively

elemental analyser. The technical details are described by (Leuenberger 2007). Results of $\delta^{13} \mathrm{C}$ are reported in permille (\%o) relative to Vienna Pee Dee Belemnite (VPDB) (1). The standard deviations of duplicates are to $90 \%$ within $0.3 \%$ with an overall mean standard deviation of $0.13 \%$.

$\delta^{13} \mathrm{C}(\%)=\frac{\left(\frac{13 \mathrm{c}}{12 \mathrm{c}}\right)_{\text {sample }}-\left(\frac{13 \mathrm{c}}{12 \mathrm{c}}\right)_{\text {standard }}}{\left(\frac{13_{\mathrm{c}}}{12 \mathrm{C}}\right)_{\text {standard }}} \times 1,000$.

The carbon isotope records are represented in Figs. 2 and 3 for the periods AD 1780-1825 and AD 1960-1994, respectively. The results were corrected for the change in the carbon isotopic composition of atmospheric $\mathrm{CO}_{2}$ after (Leuenberger 2007). The observed offset $\left(\delta^{13} \mathrm{C}_{\mathrm{LW}-\mathrm{EW}}\right)$ was calculated as the difference of $\delta^{13} \mathrm{C}_{\mathrm{LW}}$ and $\delta^{13} \mathrm{C}_{\mathrm{EW}}$ for each year. Among EWs-EWs, LWs-LWs and EWs-LWs, we calculated Pearson's correlation coefficient.

Pearson's correlation was also calculated between isotopic and TRW data and different monthly temperature, precipitation and North Atlantic Oscillation (NAO) time series over the periods AD 1780-1825 and AD 1960-1994 (Figs. 4, 5, respectively). We used the monthly Nord-West regional HISTALP and the four closest grid points of Casty temperature and precipitation reconstruction 
Fig. 2 Early- and latewood $\delta^{13} \mathrm{C}$ isotopic composition of annual tree ring cellulose obtained of Quercus petraea, over the 45-year period (AD 1780-1825). The solid black, the dashed and the dotted line represent the difference between $\delta^{13} \mathrm{C}_{\mathrm{LW}}$ and $\delta^{13} \mathrm{C}_{\mathrm{EW}}$, the trend line of the difference between $\delta^{13} \mathrm{C}_{\mathrm{LW}}$ and $\delta^{13} \mathrm{C}_{\mathrm{EW}}$ and the mean difference between $\delta^{13} \mathrm{C}_{\mathrm{LW}}$ and $\delta^{13} \mathrm{C}_{\mathrm{EW}}$, respectively

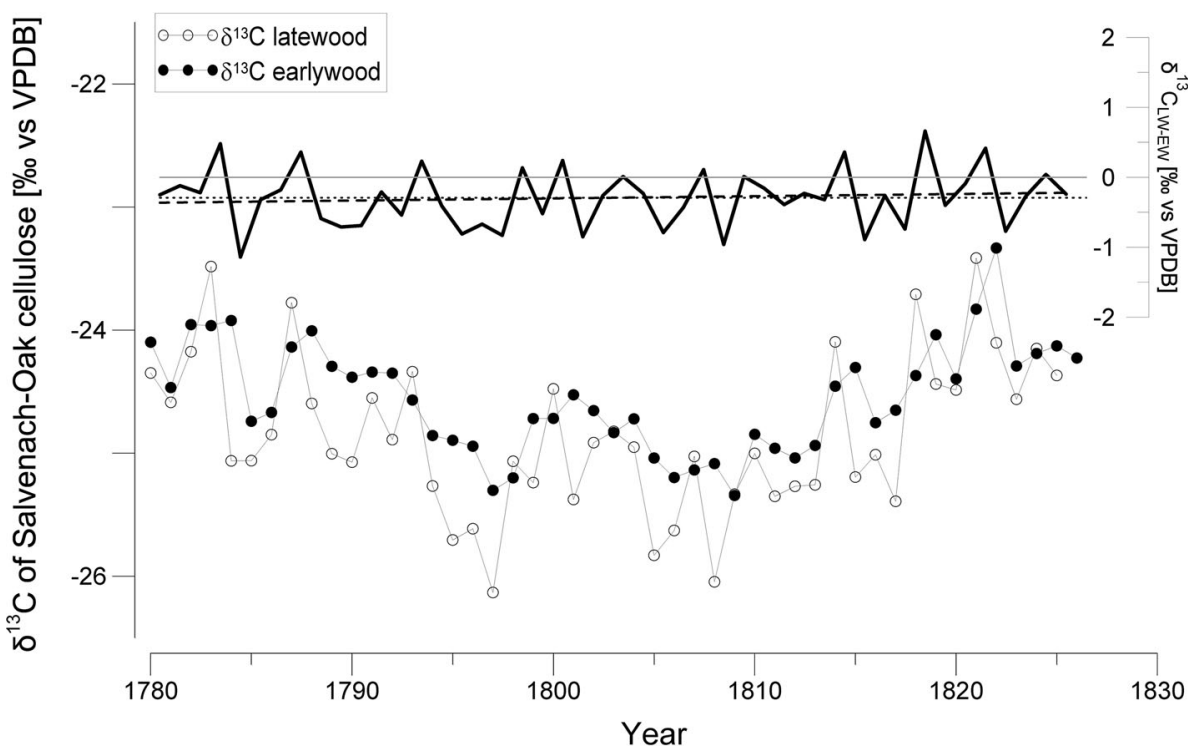

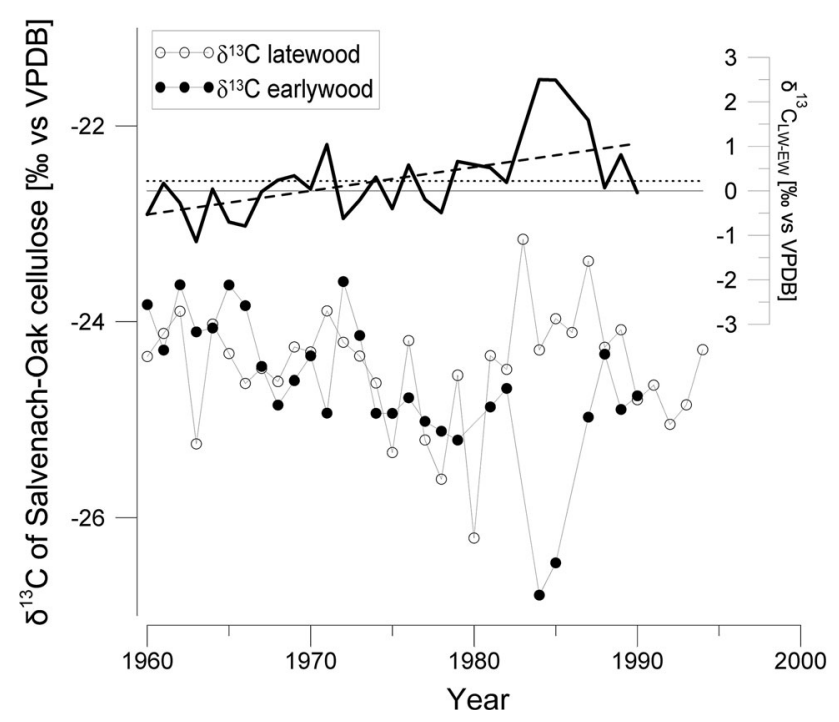

Fig. 3 Early- and latewood $\delta^{13} \mathrm{C}$ isotopic composition of annual tree ring cellulose obtained of Quercus petraea., over the 35-year period (AD 1960-1994). The solid black, the dashed and the dotted line represent the difference between $\delta^{13} \mathrm{C}_{\mathrm{LW}}$ and $\delta^{13} \mathrm{C}_{\mathrm{EW}}$, the trend line of the difference between $\delta^{13} \mathrm{C}_{\mathrm{LW}}$ and $\delta^{13} \mathrm{C}_{\mathrm{EW}}$ and the mean difference between $\delta^{13} \mathrm{C}_{\mathrm{LW}}$ and $\delta^{13} \mathrm{C}_{\mathrm{EW}}$, respectively

(Auer et al. 2007; Casty et al. 2005), moreover the NAO index reconstruction described by Luterbacher et al. (2002).

\section{Results}

The results of carbon stable isotopic measurements from AD 1780-1825 and AD 1960-1994 show distinct differences in the influence of reserves on EW: (1) While EW shows a lower variance than LW in the first period, similar variance is observed in the second period; (2) EW appears to be shifted by 1 year as expected (documenting the influence of previous LW on current year EW) compared to LW in the first period but it is by far less obvious in the second period and (3) EW is less negative than LW as expected with an influence of the enriched $\delta^{13} \mathrm{C}$ values of reserves, in particular in the first period. The differences between LW and EW fluctuate between -1 and $0.6 \%$ for the first cold period, whereas for the second warm period they fluctuate between -1 and $3 \%$. Furthermore, there is no trend visible for the cold period in contrast to the warm period, which shows a positive trend of the difference indicating a diminished influence of reserves on EW.

Response to changing climate conditions

\section{Temperature}

Many previous studies documented different impacts on stable isotopes and tree ring width (TRW). Due to assimilation, a high coherence is expected between carbon isotopes and air temperature of summer months which is very well-documented by (Kress et al. 2009a; Loader et al. 2008; Robertson et al. 1997), but lower or negative correlations were observed too (Kern et al. 2013; Szcepanek et al. 2006). These contrasting results are most probably due to the influence of site specific conditions. Following the Farquhar equation (Farquhar et al. 1982), for above optimal temperatures the stomata are more restrictive (to optimise the assimilation versus water loss) resulting in a reduced ${ }^{13} \mathrm{C}$ discrimination due to a lower $\mathrm{CO}_{2}$ concentration in the leaf. Thus, $\delta^{13} \mathrm{C}$ values follow temperature changes documented by positive correlations. 
$1780-1825$

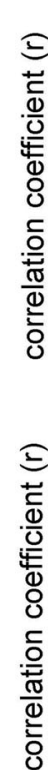

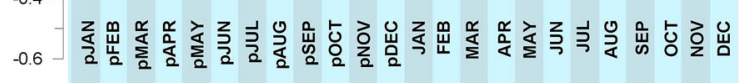

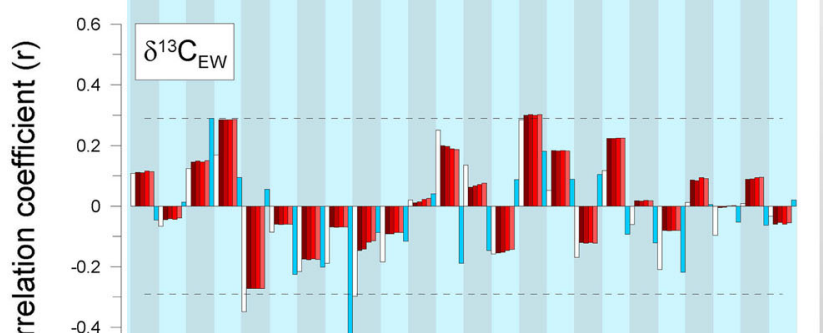

$-0.4$

$\delta^{13} \mathrm{C}_{\mathrm{WW}}$

04

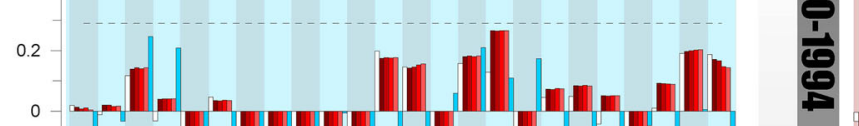

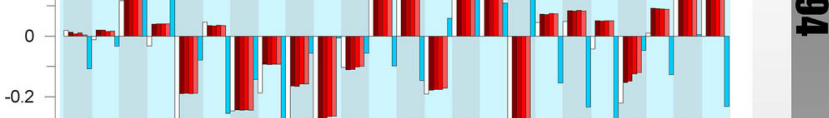

有

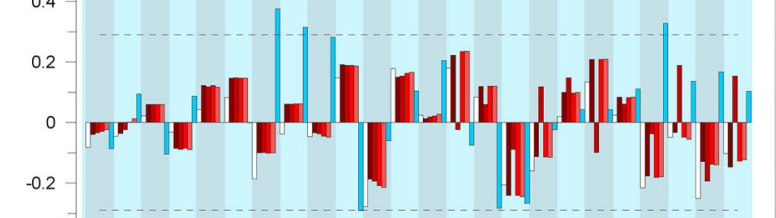

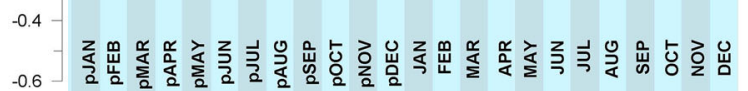

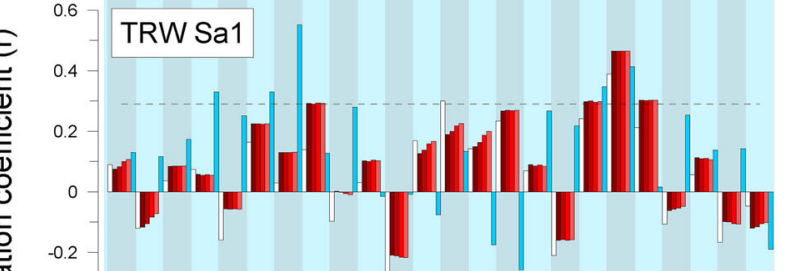

은

$-0.4$

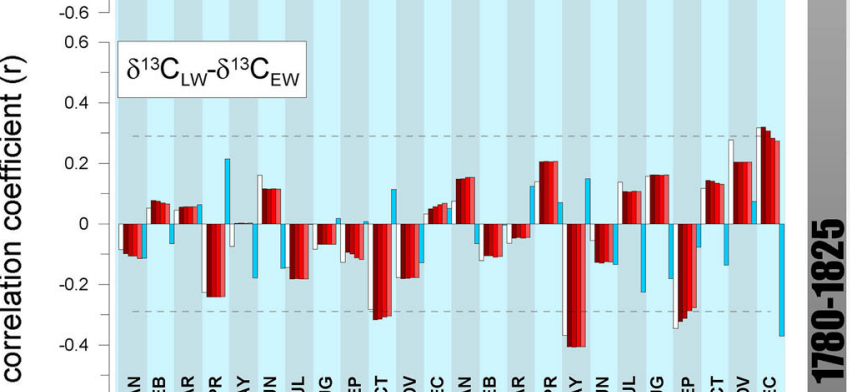

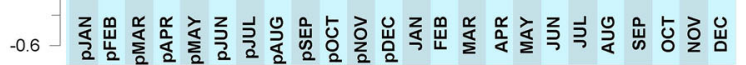

$1960-1994$

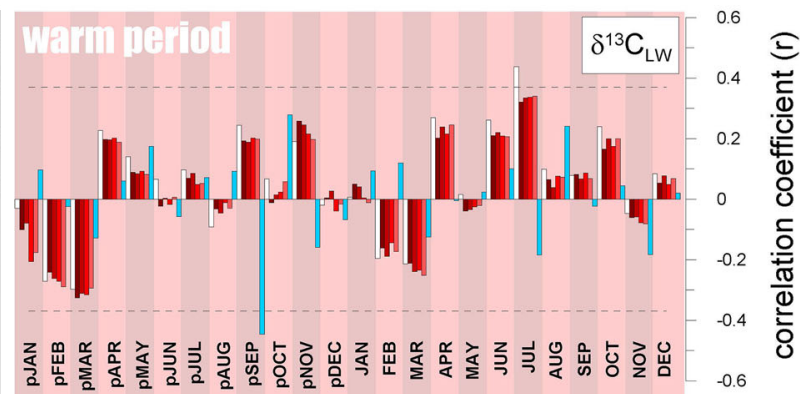

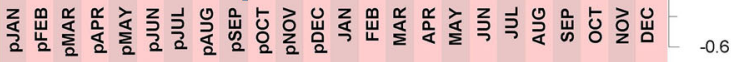

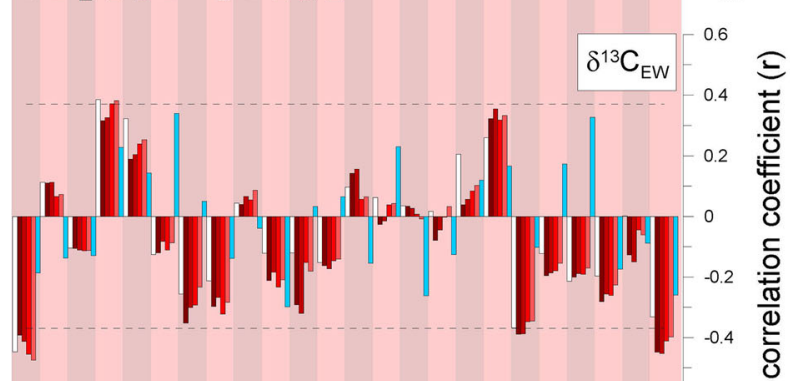

$-0.6$

0.6

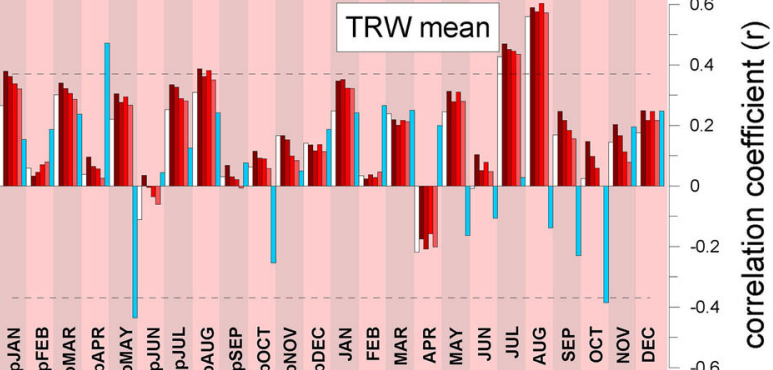

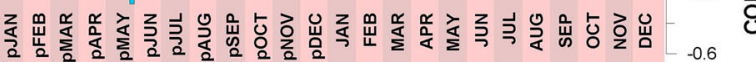

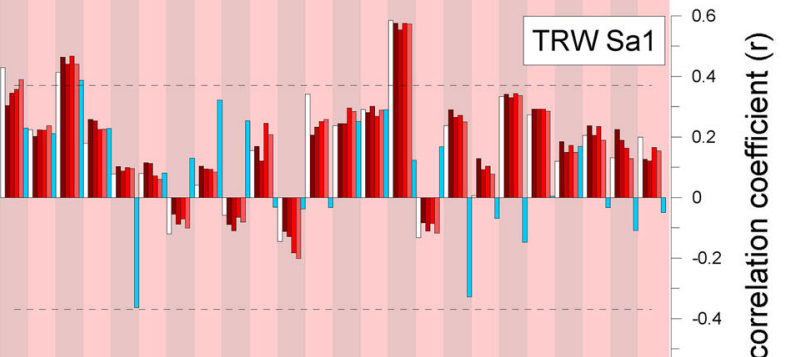

$-0.6$

0.6

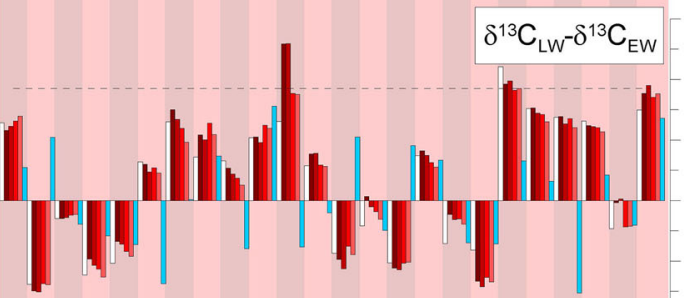

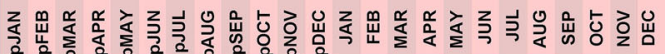

Fig. 4 Monthly temperature and NAO index reconstructions compared with $\delta^{13} \mathrm{C}_{\mathrm{LW}}, \delta^{13} \mathrm{C}_{\mathrm{EW}}$, TRW mean, TRW Sa1 and $\delta^{13} \mathrm{C}_{\mathrm{LW}^{-}}$ $\delta^{13} \mathrm{C}_{\mathrm{EW}}$ over the period $\mathrm{AD} 17801825$ (indicated as cold period) and
AD 1960-1994 (indicated as warm period). The dashed line represents the significance level of $p<0.05$ for each case. pJAN means January of the previous year 
$1780-1825$

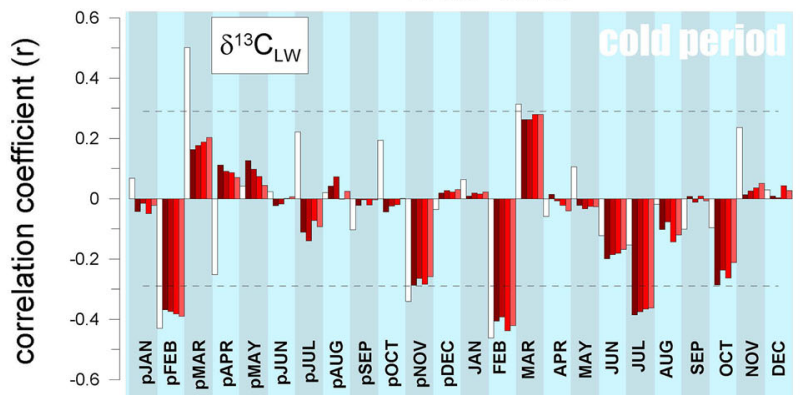

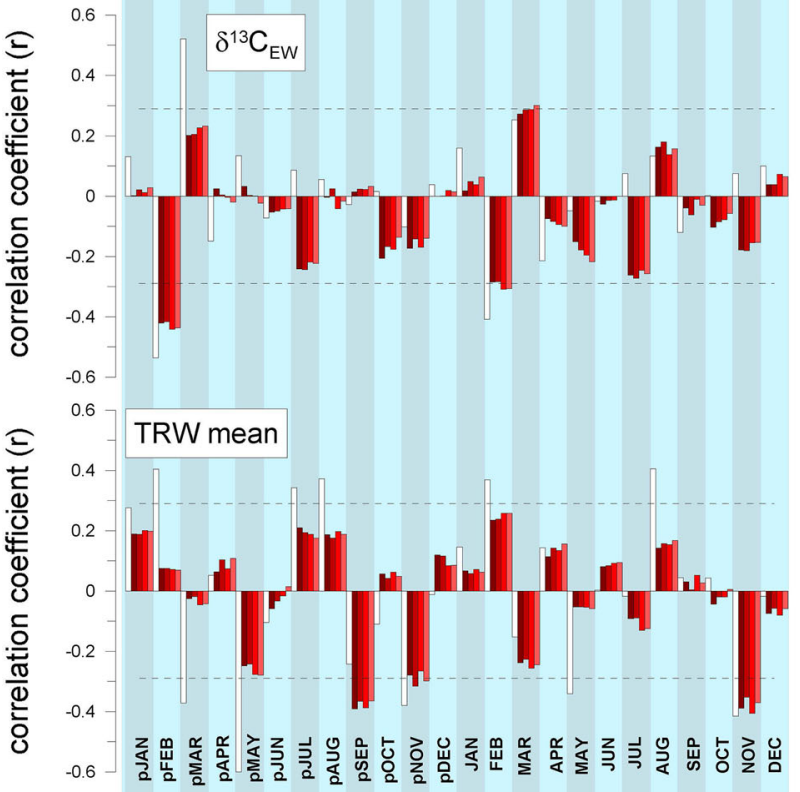

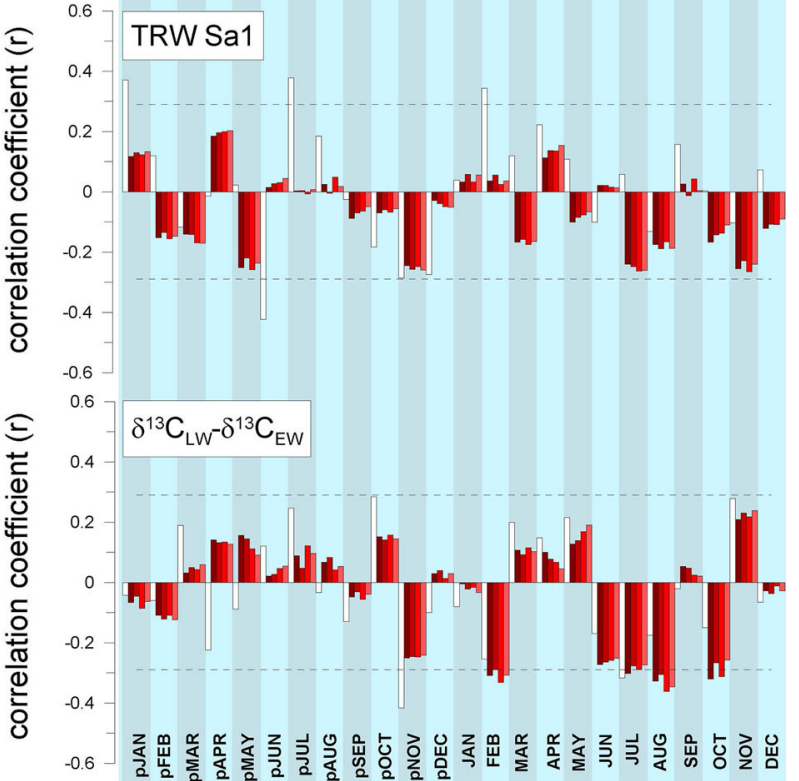

CASTY/A - $46^{\circ} 45^{\prime} \mathrm{N} / 6^{\circ} 45^{\prime} \mathrm{E}$

Fig. 5 Monthly precipitation reconstructions compared with $\delta^{13} \mathrm{C}_{\mathrm{LW}}$, $\delta^{13} \mathrm{C}_{\mathrm{EW}}$, TRW mean, TRW Sa1 and $\delta^{13} \mathrm{C}_{\mathrm{LW}}-\delta^{13} \mathrm{C}_{\mathrm{EW}}$ over the period $\mathrm{AD}$ 1780-1825 (indicated as cold period) and AD 1960-1994 (indicated

1960-1994

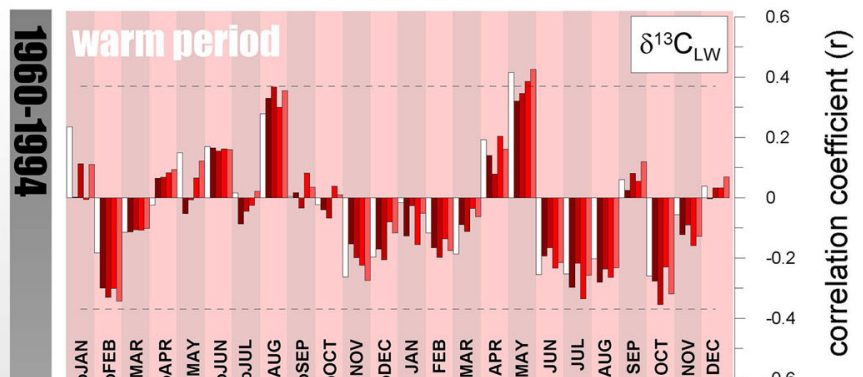

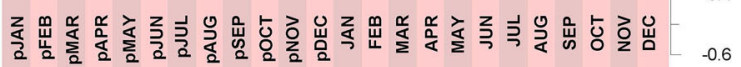
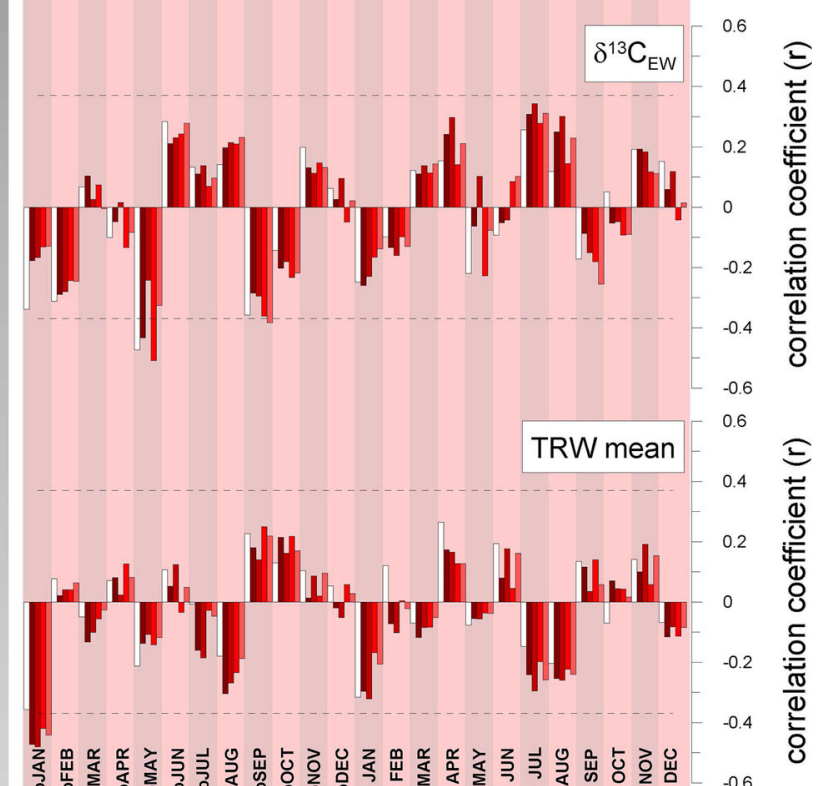

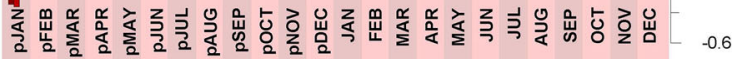
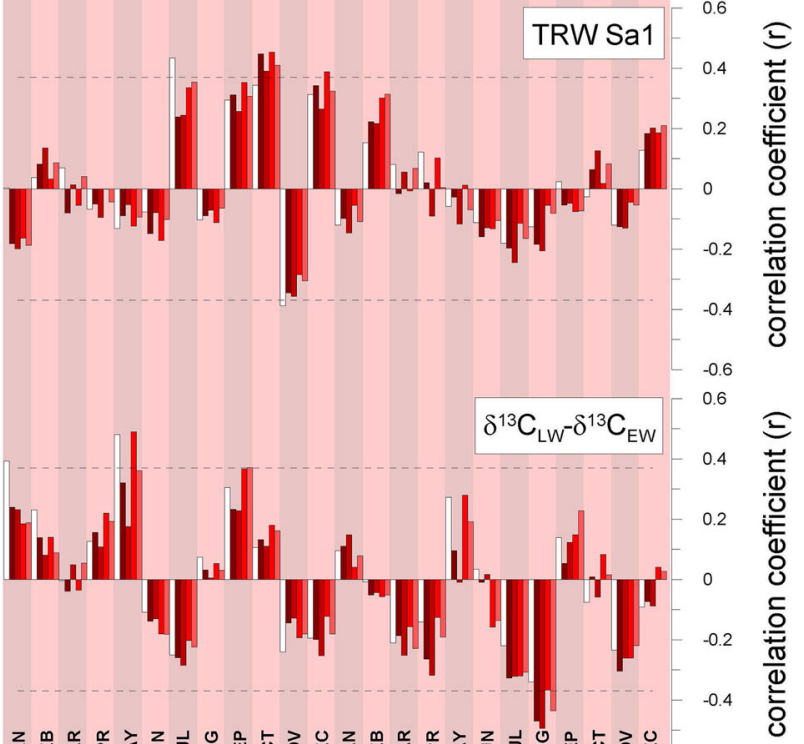

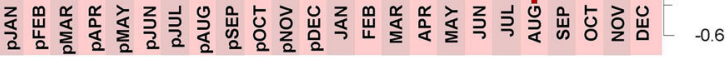

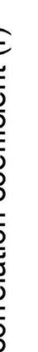


In this respect the two investigated periods are helpful. The first chosen period AD 1780-1825 is a well-known cold period with a $\mathrm{CO}_{2}$ concentration around 280-290 ppm, the period $\mathrm{AD}$ 1960-1994 exhibits increasing temperature and $\mathrm{CO}_{2}$ concentrations around 320-360 ppm (Leuenberger 2007), while the hydrological conditions of the site did not change.

Due to the phenology of deciduous trees we expected positive correlation with summer months for $\delta^{13} \mathrm{C}_{\mathrm{LW}}$-and TRW time series and positive correlation with spring and previous year summer months for $\delta^{13} C_{E W}$. However, we hardly found any significant correlations in the cold period, except for a slightly significant positive correlation between $\delta^{13} \mathrm{C}_{\mathrm{EW}}$ and March $(r=30 \%)$, but surprisingly a seasonal pattern of NAO index appeared. Both EW and LW carbon isotope compositions correlate positively with spring months' (March, April) and negatively with late summer months' (July, August) NAO indices. Moreover, only the TRW Sal record has the expected significant positive correlation with summer months' temperature.

During the warm period $\mathrm{AD} 1960-1994 \delta^{13} \mathrm{C}_{\mathrm{LW}}$ documents only a significant correlation $(r=43 \%)$ with July temperature of the HISTALP dataset. No other significant correlation was found. The $\delta^{13} \mathrm{C}_{\mathrm{EW}}$ has no correlation with spring months, a close to significant positive correlation with June $(r=35 \%)$ and only slightly significant positive correlation with previous year April and May $(r=38 \%)$. The tree growth has positive correlation with summer months' temperature in this case too ( $r=40-60 \%)$, while for TRW Sal no significant positive correlation with summer months were found.

Consequently, the carbon isotopic time series do not show the expected correlations, neither for the cold nor the warm time period despite the active tree growth. However, based on our results, we have indications that the increasing temperature in the last century has an impact not only on tree ring growth but on isotope fractionation, too. These indications are based on the correlation calculations (Fig. 4) between tree ring width (growth) and temperature that significantly increased from the earlier to the later period. Similar changes, though to a lesser degree, have been found for $\delta^{13} \mathrm{C}$ and temperature. The latter correlation is most probably not a direct temperature correlation since studies several decades ago documented the biochemical carbon fractionation to be temperature independent (Christeller and Laing 1975; O'Leary 1981). However, it might point to an indirect link of the increasing $\mathrm{CO}_{2}$ concentration on temperature as published by McCarroll et al. (2009) and (Schubert and Jahren 2012).

\section{Precipitation}

Single precipitation events have hardly an influence on $\delta^{13} \mathrm{C}$ of EW and LW, however extended periods of dryness or wetness will influence it through changes in the availability of water and therefore in the leaf conductivity. Therefore, the amount of precipitation can help us to determine the inter-annual hydrological conditions of the sampling site, i.e. the stomatal activity as well as the soil water availability. In our case, the comparisons between isotopic records and precipitation show a very high variability. The only significant pattern was found for TRW Sa1 for the warm period, where the tree ring growth correlates positively with the previous years' precipitation except spring. This points to a 5-6 months shift until the precipitation is available for the cell formation as groundwater. This time shift seen by the trees is somewhat supported by negative correlations of $\delta^{13} \mathrm{C}$ values of $\mathrm{EW}$ and $\mathrm{LW}$ with spring precipitation for both periods.

\section{Autocorrelations among EWs and LWs}

To establish the main difference between the cold and the warm period, we investigated inter- and intra- annual relations for EWs and LWs. Based on our hypothesis that the physiological processes, i.e. assimilation and redistribution of carbon within the tree, in cold and warm periods behave differently in reaction rate, efficiency, fluid cavitation potential (drought) and their contribution percentage, we expected changing relations. Figures 4, 5 show us the correlation tendency of current year EW $\left(\mathrm{EW}_{\mathrm{t}}\right)$ and $\mathrm{LW}\left(\mathrm{LW}_{\mathrm{t}}\right)$ with EWs and LWs from the previous 10 years.

During the cold period (Fig. 6), the current year LW has very low correlations with previous LWs as well as with EWs except with the current EW $\left(r^{2}=56 \%\right.$, the last part of EW (transition zone) was built from assimilates that are also used for the current LW). This may point to a high inter-annual variability of assimilates. Moreover, after the $t-5$ year, the common signal disappears.

The current year EW has the above-mentioned correlation with current year LW $\left(r^{2}=56 \%\right)$. However, the highest relation we found with previous year LW $\left(r^{2}=68 \%\right)$ indicating that a large part of the used carbohydrates was transferred from the previous year carbon reserves built during the previous year LW formation. Until $t-8$ we found steadily decreasing correlation coefficients, whereupon the signal disappears.

With changed climate conditions during the period $\mathrm{AD}$ 1960-1994 (Fig. 7), we do not find the above-mentioned correlations anymore. The higher correlations for the current year LW have vanished just like for current year EW. Only slight correlations were found between current year EW and previous year EW.

\section{Discussion and conclusion}

We measured carbon isotopes in a single oak tree from a site in Switzerland for two selected time periods, i.e. from 
AD1780-1825

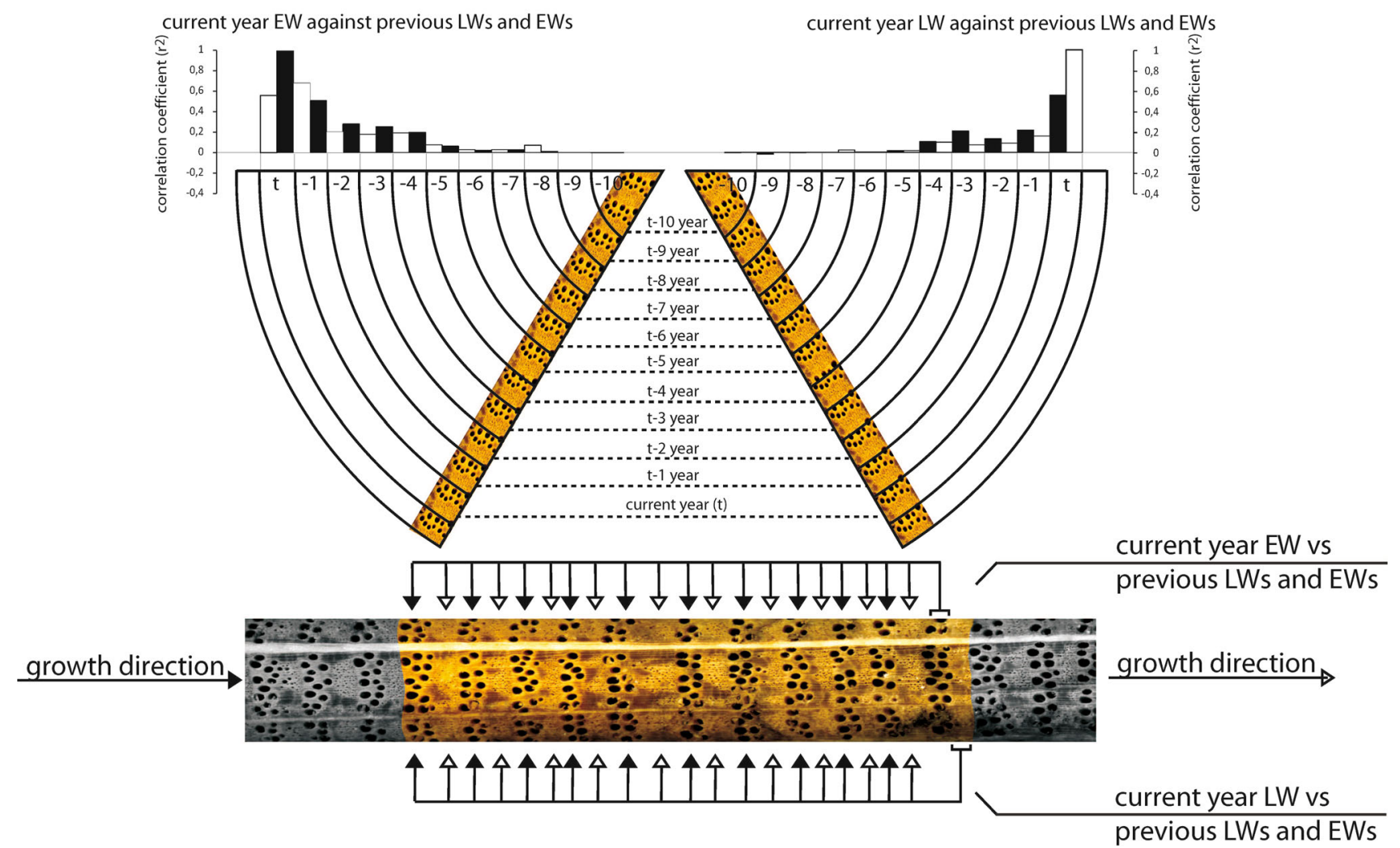

Fig. 6 Correlation coefficients $\left(r^{2}\right)$ of isotopic time series between current year EW (left side) and LW (right side) and EWs and LWs from previous years over the period AD 1780-1825. Black bars

AD 1780 to 1825 and from AD 1960 to 1994, representing a warm and a cold state. These two marked periods were found to be especially suited to determine the upshots of climate anomalies and different impacts on tree rings, influenced by temperature and atmospheric $\mathrm{CO}_{2}$ concentration changes and to a lesser extent by precipitation. In particular, we determined how tree physiology reacts to climate change at the Salvenach site. However, the heterogeneity of site conditions prevents us to upscale our results in a robust manner to other locations.

For both time periods, we found unexpected low correlations between isotope time series and summer monthly temperatures. The weak correlations that have been observed with prior years for LW during the cold period maybe because the tree was not able to produce enough assimilates due to the cold conditions which might have resulted in an enhanced support from the carbon storage for tree ring formation. Our observations indicate that the tree could not completely fill up the carbon storage so that the reserves were relatively young, while the assimilation rate was probably low, inducing a strong autocorrelation between $\delta^{13} \mathrm{C}$ time series for the period AD 1780-1825 (Fig. 6). The lower measured mean indicate EWs while white bars indicate LWs. The $x$ axis means the different EWs and LWs where " $t$ " means current year, " $t-1$ ", " $t-2$ ", etc. mean previous years, respectively

TRW $(294 \mu \mathrm{m})$ for the cold period are supported by the lack of positive correlation with summer temperatures. Thus, very low correlations were found for $\delta^{13} C_{L W}$ with temperature.

Moreover, the correlation patterns show a seasonal influence by NAO index for both $\delta^{13} \mathrm{C}_{\mathrm{EW}}$ and $\delta^{13} \mathrm{C}_{\mathrm{LW}}$ time series for AD 1780-1825. Positive correlations are observed with spring months and negative with summer months of the current and previous year. This might indicate an indirect effect on prime parameter for tree ring growth [i.e. relative humidity, cloudiness or sunshine duration (Sanchez-Lorenzo et al. 2009)] induced by NAO over this period besides temperature and precipitation which show no correlation with NAO.

In addition, prior to budburst no direct assimilation of carbohydrates is possible. The only source to start the cell formation is carbohydrate reserves from previous years and the still remaining soluble carbohydrates from winter that support the tree against cold damage (Ashworth et al. 1993). These substances are used to build the EW cells, including their characteristic large vessels, and therefore carry information about previous years. Depending on the evolution of meteorological conditions during the 
AD1960-1994

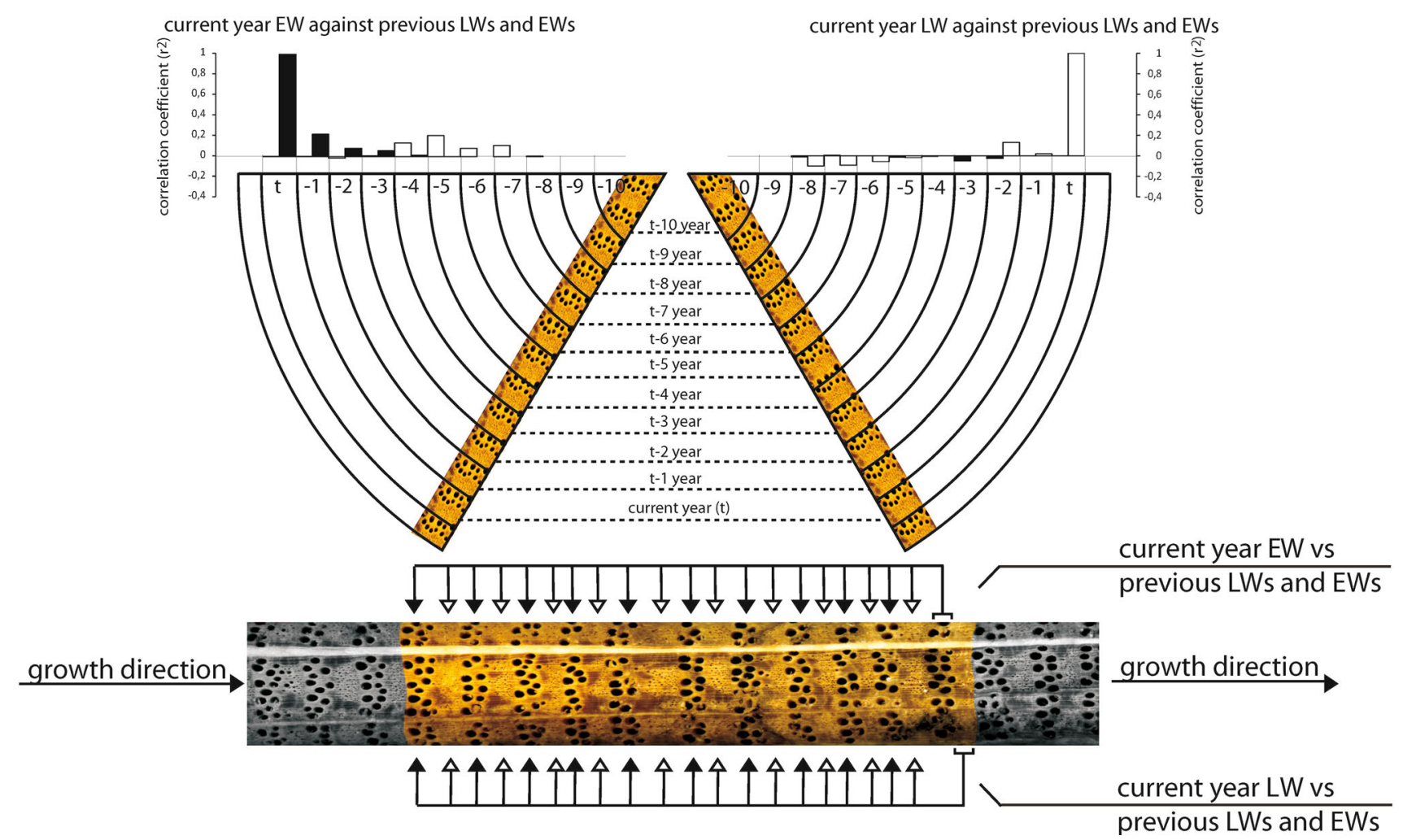

Fig. 7 Correlation coefficients $\left(r^{2}\right)$ of isotopic time series between current year EW (left side) and LW (right side) and EWs and LWs from previous years over the period AD 1960-1994. Black bars

continuation of EW formation, EW represents either signals from previous years (reserves) under extreme conditions (very cold, very dry, very low sunshine duration) or from current year spring time (new assimilates) under normal conditions. LW on the contrary represents the actual meteorological conditions via photosynthetic products. Therefore, low agreement is expected between current year LW and previous years' LWs, however, good agreement is expected between current year EW and previous year LW for bad to normal site conditions (high to normal reserve usage) and a lack of agreement under good to excellent site conditions (hardly any reserves in use).

The prevailing cold condition enhances this fact, documented by the high correlations between current year EW and current year LW. Due to the unfavorable conditions during AD 1780-1825, the reserves account for a larger part in EW inducing a high correlation with previous year LW, shown in Fig. 6. While decreasing correlations with previous LWs back to $t-9$ years reveal the increased reserve usage at the same time. Additionally, correlations between current year LW and previous LWs evidence intensive usage of previous years' reserves under unfavorable meteorological conditions. indicate EWs while white bars indicate LWs. The $x$ axis means the different EWs and LWs where " $t$ " means current year, " $t-1$ ", " $t-2$ ", etc. mean previous years, respectively

For the period AD 1960-1994, low correlations are found between $\delta^{13} \mathrm{C}_{\mathrm{EW}}$ and $\delta^{13} \mathrm{C}_{\mathrm{LW}}$ (Fig. 7). In our view, it indicates the fact that under good climate conditions (increased temperature and higher $\mathrm{CO}_{2}$ concentrations) the leaf formation of trees goes well and reserves contribute in a limited way to the EW. However, it may also be the result of a signal loss due to the rapid mixing of carbon storage (Keel et al. 2007). The only correlation was found between current year EW and previous year EW indicating at least a contribution to the EW from the previous year.

Positive significant correlations were found for the $\delta^{13} \mathrm{C}_{\mathrm{LW}}$ only in one case, with the HISTALP Bern temperature time series. In contrast, the TRW mean shows a better relation with summer temperatures which means that the air temperature has a dominant influence on tree ring growth but not on the isotope composition of LW cellulose.

The offset defined as difference of $\delta^{13} \mathrm{C}_{\mathrm{LW}}$ and $\delta^{13} \mathrm{C}_{\mathrm{EW}}$ (Figs. 2, 3) is expected to be negative since the $\delta^{13} \mathrm{C}_{\mathrm{EW}}$ signal is believed to be more positive than the $\delta^{13} \mathrm{C}_{\mathrm{LW}}$ signal due to a contribution of the enriched reserves (Rossmann et al. 1991; Tcherkez et al. 2004) used for the leaf and tree ring formation at the start of the vegetation period. Theoretically, under constant climate conditions the 
mean offset should remain the same but with moderate inter-annual variability. Indeed we observed a constant offset with higher fluctuations induced by sudden decreases and increases of the $\delta^{13} \mathrm{C}_{\mathrm{LW}}$ isotopic signal compared to the $\delta^{13} \mathrm{C}_{\mathrm{EW}}$ signal for the period $\mathrm{AD} 1780-1825$. These fluctuations may be driven by inter-annual changes of site meteorological conditions or more plausible by weather extremes, e.g. volcano eruptions (Laki AD 1783, unidentified eruption AD 1809 and Tambora AD 1815) for the case of negative deviations. In agreement to the temperature decreases observed after eruptions, $\delta^{13} \mathrm{C}_{\mathrm{LW}}$ shows more negative values. Moreover, in contrast to $\delta^{13} \mathrm{C}_{\mathrm{LW}}$, the TRW Sal time series documents positive correlations with summer temperature, indicating that temperature influences the tree ring growth but not the carbon isotopic composition of cellulose (Fig. 4). No correlations were found for the offset with temperature (highly variable) but a negative correlation with summer months' precipitation.

In contrast, the $\delta^{13} \mathrm{C}_{\mathrm{LW}}-\delta^{13} \mathrm{C}_{\mathrm{EW}}$ offset is different during $\mathrm{AD}$ 1960-1994 by exhibiting a positive trend with similar short-term fluctuations as for the cold period. The trend is, however, mainly determined by some values in the 1980's. Nevertheless, it could indicate an influence of changed conditions (increase in temperature and $\mathrm{CO}_{2}$ concentrations) that might lead to a lower dependence of EW on reserves of previous years documented by the lack of dependence shown in Fig. 7. Correlations with summer temperatures improved compared to the cold period but are only partly significant whereas correlations with summer precipitation remained significant, which supports our expectation that the hydrological conditions have not changed over time at the site. The variability of $\delta^{13} \mathrm{C}_{\mathrm{EW}}$ seems to have increased from the cold to the warm period. This is supported by our finding that the correlation pattern of $\delta^{13} \mathrm{C}_{\mathrm{LW}}$ and the offset with temperature is very similar (Fig. 4, uppermost and lowermost panel) for the cold period for which we found a clear dependence of EW with contributions of reserves, i.e. previous years' carbohydrates (see Fig. 6).

In summary, the two time periods exhibit significant differences that indicate a change of the carbon storage influence on tree growth and the isotopic composition. The different meteorological conditions dictate changes in the carbon storage and therewith in the carbon stable isotopic compositions of tree ring cellulose. For cold periods, smoothed multi-annual variability is recorded (dominance by reserves); whereas for warm periods, annual variability (dominance by assimilation) is displayed by the isotope series of tree ring cellulose. The interpretation of isotope records needs to take this storage influence (plant physiological strategies) into account to properly address variations to different influencing processes. However, in upcoming studies one needs to show whether analyses on multiple tree cores from the same tree and among different trees support our findings.

Author contribution statement M.L. designed the conception of this study. A.K. prepared the experiments and carried out the analysis of isotope measurements. The statistical analyses and interpretation were implemented by A.K. Drafting of manuscript was carried out by A.K. Moreover, M.L carried out the critical revision.

Acknowledgments We would like to thank Peter Nyfeler for his help with the measurements. This work was supported by the project SNF-iTREE (Project Number: 136295).

Conflict of interest The authors declare that they have no conflict of interest.

Open Access This article is distributed under the terms of the Creative Commons Attribution License which permits any use, distribution, and reproduction in any medium, provided the original author(s) and the source are credited.

\section{References}

Ashworth EN, Stirm VE, Volenec JJ (1993) Seasonal variations in soluble sugars and starch within woody stems of Cornus sericea L. Tree Physiol 13:379-388. doi:10.1093/treephys/13.4.379

Auer I et al (2007) HISTALP-historical instrumental climatological surface time series of the Greater Alpine Region. Int J Climatol 27:17-46. doi:10.1002/joc. 1377

Barbaroux C, Bréda N (2002) Contrasting distribution and seasonal dynamics of carbohydrate reserves in stem wood of adult ringporous sessile oak and diffuse-porous beech trees. Tree Physiol 22:1201-1210. doi:10.1093/treephys/22.17.1201

Boettger $\mathrm{T}$ et al (2007) Wood Cellulose preparation methods and mass spectrometric analyses of $\delta^{13} \mathrm{C}, \delta^{18} \mathrm{O}$ and non-exchangeable $\delta^{2} \mathrm{H}$ values in cellulose, sugar and starch- an interlaboratory comparison. Anal Chem 79:4603-4612. doi:10.1021/ac0700023

Borella S, Leuenberger M, Saurer M, Siegwolf R (1998) Reducing uncertainties in $\delta 13 \mathrm{C}$ analysis of tree rings: pooling, milling, and cellulose extraction. J Geophys Res 103:19519-19526. doi:10. 1029/98jd01169

Büntgen U, Frank DC, Nievergelt D, Esper J (2006) Summer temperature variations in the european alps $755-2004$. J Clim 19:5606-5623

Casty C, Wanner H, Luterbacher J, Esper J, Böhm R (2005) Temperature and precipitation variability in the European Alps since 1500. Int J Climatol 25:1855-1880. doi:10.1002/joc.1216

Chmielewski F-M, Müller A, Bruns E (2004) Climate changes and trends in phenology of fruit trees and field crops in Germany, 1961-2000. Agric For Meteorol 121:69-78. doi:10.1016/s01681923(03)00161-8

Christeller JT, Laing WA (1975) Isotope discrimination by ribulose 1,5-diphosphate carboxylase. Plant Physiol 57:580-582

Defila C, Clot B (2005) Phytophenological trends in the Swiss Alps, 1951-2002. Meteorol Z 14:191-196. doi:10.1127/0941-2948/ 2005/0021

Farquhar GD, O'Leary MH, Berry JA (1982) On the Relationship between Carbon Isotope Discrimination ad the Intercellular Carbon Dioxide Concentration in Leaves. Aus J Plant Physiol 9:121-137. doi:10.1071/PP9820121

Feuillat F, Keller R (1997) Variability of oak wood (Quercus robur L., Quercus petraea Liebl.) anatomy relating to cask properties. Am J Enol Vitic 48:502-508 
Gao C, Robock A, Ammann C (2008) Volcanic forcing of climate over the past 1500 years: an improved ice core-based index for climate models. J Geophys Res 113:D23111. doi:10.1029/2008jd010239

Gessler A, Tcherkez G, Peuke AD, Ghashghaie J, Farquhar GD (2008) Experimental evidence for diel variations of the carbon isotope composition in leaf, stem and phloem sap organic matter in Ricinus communis. Plant Cell Environ 31:941-953. doi:10. 1111/j.1365-3040.2008.01806.x

Gessler A, Brandes E, Buchmann N, Helle G, Rennenberg H, Barnard RL (2009) Tracing carbon and oxygen isotope signals from newly assimilated sugars in the leaves to the tree-ring archive. Plant Cell Environ 32:780-795. doi:10.1111/j.1365-3040.2009.01957.x

Gessler A, Ferrio JP, Hommel R, Treydte K, Werner RA, Monson RK (2014) Stable isotopes in tree rings: towards a mechanistic understanding of isotope fractionation and mixing processes from the leaves to the wood. Tree Physiol 34:796-818. doi:10. 1093/treephys/tpu040

Helle G, Schleser GH (2004) Beyond $\mathrm{CO}_{2}$-fixation by Rubisco-an interpretation of ${ }^{12} \mathrm{C}-{ }^{13} \mathrm{C}$ variations in tree rings from novel intra-seasonal. Plant Cell Environ 27:367-380. doi:10.1111/j. 1365-3040-.2008.01806x

Hill S, Waterhouse JS, Field E, Switsur VR, Rees APT (1995) Rapid recycling of triose phosphates in oak stem tissue. Plant Cell Environ 18:931-936. doi:10.1111/j.1365-3040.1995.tb00603.x

Hobbie E, Werner RA (2004) Intermolecular, compound-specific, and bulk carbon isotope patterns in $\mathrm{C} 3$ and $\mathrm{C} 4$ plants: a review and synthesis. New Phytol 161:371-385. doi:10.1046/j.1469-8137. 2004.00970.x

IPCC (2013) Climate change 2013: the physical science basis. Contribution of working group I. to the fifth assessment report of the intergovernmental panel on climate change. Cambridge University Press, Cambridge

Jäggi M, Saurer M, Fuhrer J, Siegwolf R (2002) The relationship between the stable carbon isotope composition of needle bulk material, starch, and tree rings in Picea abies. Oecologia 131:325-332. doi:10.1007/s00442-002-0881-0

Keel SG, Schadel C (2010) Expanding leaves of mature deciduous forest trees rapidly become autotrophic. Tree Physiol 30:1253-1259. doi:10.1093/treephys/tpq071

Keel SG, Siegwolf RT, Jaggi M, Korner C (2007) Rapid mixing between old and new $\mathrm{C}$ pools in the canopy of mature forest trees. Plant Cell Environ 30:963-972. doi:10.1111/j.1365-3040.2007.01688.x

Kern Z, Patkó M, Kázmér M, Fekete J, Kele S, Pályi Z (2013) Multiple tree-ring proxies (earlywood width, latewood width and 813C) from pedunculate oak (Quercus robur L.), Hungary. Quat Int 293:257-267. doi:10.1016/j.quaint.2012.05.037

Kozlowski TT (1992) Carbohydrate Sources ans sinks in woody plants. Bot Rev. doi:10.1007/BF02858600

Kress A, Saurer M, Buntgen U, Treydte KS, Bugmann H, Siegwolf RT (2009a) Summer temperature dependency of larch budmoth outbreaks revealed by Alpine tree-ring isotope chronologies. Oecologia 160:353-365. doi:10.1007/s00442-009-1290-4

Kress A, Young GHF, Saurer M, Loader NJ, Siegwolf RTW, McCarroll D (2009b) Stable isotope coherence in the earlywood and latewood of tree-line conifers. Chem Geol 268:52-57. doi:10.1016/j.chemgeo.2009.07.008

Laumer W, Andreu L, Helle G, Schleser GH, Wieloch T, Wissel H (2009) A novel approach for the homogenization of cellulose to use micro-amounts for stable isotope analyses. Rapid Commun Mass Spectrom 23:1934-1940. doi:10.1002/rcm.4105

Leavitt SW (2010) Tree-ring C-H-O isotope variability and sampling. Sci Total Environ 408:5244-5253. doi:10.1016/j.scitotenv.2010. 07.057

Leuenberger M (2007) To what extent can ice core data contribute to the understanding of plant ecological developments of the past? Terr Ecol 1:211-233. doi:10.1016/s1936-7961(07)01014-7
Leuenberger M, Borella S, Stocker TF, Saurer M, Siegwolf R, Schweingruber FH, Matyssek R (1998) Stable isotopes in tree rings as climate and stress indicators. Verlag der Fachvereine Hochschulverlag AG an der ETH Zürich, Zurich

Li Z, Leavitt S, Mora C, Liu R (2005) Influence of earlywood-latewood size and isotope differences on long-term tree-ring $\delta^{13} \mathrm{C}$ trends. Chem Geol 216:191-201. doi:10.1016/j.chemgeo.2004.11.007

Loader NJ, Robertson I, McCarroll D (2003) Comparison of stable carbon isotope ratios in the whole wood, cellulose and lignin of oak tree-rings. Palaeogeogr Palaeoclimatol Palaeoecol 196:395-407. doi:10.1016/s0031-0182(03)00466-8

Loader NJ et al (2008) Multiple stable isotopes from oak trees in southwestern Scotland and the potential for stable isotope dendroclimatology in maritime climatic regions. Chem Geol 252:62-71. doi:10.1016/j.chemgeo.2008.01.006

Luterbacher $J$ et al (2002) Extending north atlantic oscillation reconstruction back to 1500. Atmos Sci Lett 2:114-124. doi:10.1006/asle.2001.0044

McCarroll D, Loader NJ (2004) Stable isotopes in tree rings. Quatern Sci Rev 23:771-801. doi:10.1016/j.quascirev.2003.06.017

McCarroll D et al (2009) Correction of tree ring stable carbon isotope chronologies for changes in the carbon dioxide content of the atmosphere. Geochim Cosmochim Acta 73:1539-1547. doi:10. 1016/j.gca.2008.11.041

McCormac FG, Baillie MGL, Pilcher JR, Brown DM, Hoper ST (1994) $\delta^{13} \mathrm{C}$ measurements from the Irish oak chronology. Radiocarbon 36:27-35

Michelot A, Simard S, Rathgeber C, Dufrene E, Damesin C (2012) Comparing the intra-annual wood formation of three European species (Fagus sylvatica, Quercus petraea and Pinus sylvestris) as related to leaf phenology and non-structural carbohydrate dynamics. Tree Physiol 32:1033-1043. doi:10.1093/treephys/ tps052

Morin X, Roy J, Sonie L, Chuine I (2010) Changes in leaf phenology of three European oak species in response to experimental climate change. New Phytol 186:900-910. doi:10.1111/j.14698137.2010.03252.x

O'Leary MH (1981) Carbon isotope fractionation in plants. Phytochemistry 20:553-567. doi:10.1016/0031-9422(81)85134-5

Pallardy SG (2008) Physiology of woody plants, Academic Press, San Diego

Rinn F (2004) LINTAB 5: Tree-ring measurement station (Electronic Brochure). http://www.rinntech.de/images/stories/PDF/LINTAB-5. pdf

Robertson I, Switsur VR, Carter AHC, Hall MA (1997) Signal strength and climate relationships in ${ }^{13} \mathrm{C} /{ }^{12} \mathrm{C}$ ratios of tree ring cellulose from oak in southwest Finland. J Geophys Res 24:1487-1490. doi:10.1029/97g101293

Rossmann A, Butzenlechner M, Schmidt H-L (1991) Evidence for a non-statistical carbon isotope distribution on natural glucose. Plant Physiol 96:609-614. doi:10.1104/pp.96.2.609

Rowell R (2005) Handbook of wood chemistry and wood composites. CRC Press, New York

Sanchez-Lorenzo A, Calbó J, Brunetti M, Deser C (2009) Dimming/ brightening over the Iberian Peninsula: trends in sunshine duration and cloud cover and their relations with atmospheric circulation. J Geophys Res. doi:10.1029/2008JD011394

Schubert BA, Jahren AH (2012) The effect of atmospheric $\mathrm{CO}_{2}$ concentration on carbon isotope fractionation in $\mathrm{C} 3$ land plants. Geochim Cosmochim Acta 96:29-43. doi:10.1016/j.gca.2012. 08.003

Schweingruber FH (1996) Tree rings and environment: dendroecology. Swiss Federal Institute for Forest, Snow and Landscape Research, Paul Haupt, Birmensdorf and Berne

Switsur VR, Waterhouse JS, Field E, Carter AHC, Loader NJ (1995) Stable isotope studies in tree rings from oak-techniques and 
some preliminary results. In: Frenzel B (ed) Problems of stable isotopes in tree-rings, lake sediments and peat-bogs as climatic evidence for the Holocene, Paläoklimaforschung European Science Foundation, Strasbourg, pp 129-140

Szcepanek M et al (2006) Hydrogen, carbon and oxygen isotopes in pine and oak tree rings from southern poland as climatic indicators in year 1900-2003. Geochronometria 25:67-76
Tcherkez G, Farquhar G, Badeck F, Ghashghaie J (2004) Theoretical considerations about carbon isotope distribution in glucose of $\mathrm{C} 3$ plants. Funct Plant Biol 31:857. doi:10.1071/fp04053

Wilkinson M, Eaton EL, Broadmeadow MSJ, Morison JIL (2012) Inter-annual variation of carbon uptake by a plantation oak woodland in south-eastern England. Biogeosciences 9:5373-5389. doi:10.5194/bg-9-5373-2012 